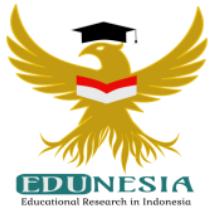

\title{
Penatalaksanaan Kegiatan Supervisi Kelas Sebagai Upaya Peningkatan Profesionalisme Guru Dalam Kegiatan Belajar Mengajar Di MTsN 3 Aceh Barat
}

\author{
Almunawar Khalil \\ Supervisi kelas, MTsN 3 Aceh Barat, Indonesia \\ Corresponding Email: alpin_35@yahoo.co.id, Phone Number : 0821 xxxx xxxx
}

\section{Article History:}

Received: Okt 08, 2020

Revised: Okt 13, 2020

Accepted: Okt 15, 2020

Published: Nov 01, 2020

\section{Keywords:}

classroom supervision, learning, professionalism.

Kata Kunci:

Pembelajaran, profesionalisme, supervisi kelas.

\section{How to cite:}

Khalil, A.

Penatalaksar Supervisi Kelas Sebagai Upaya Peningkatan Profesionalisme Guru Dalam Kegiatan Belajar. Edunesia : Jurnal Ilmiah Pendidikan, 1 (3): 97-106

This is an open access article under the CC-BY-NC-ND license

\begin{abstract}
The main issue of the implementation of this research was the low professionalism of teachers in teaching which was caused by: (1) the lack of opportunities for teachers to participate in training, both regionally and nationally; (2) less effective Teacher Working Group (KKG); and (3) educational supervision aimed at improving the learning process tends to focus on administrative aspects. The research was conducted by teachers at MTsN 3 Aceh Barat for the 2018 academic year starting from July to December, for 6 (six) months. The research subjects were 6 teachers, while the object of the research was the professionalism of teachers in implementing learning. The data was obtained by doing an observation and documentation. The results showed that the professionalism of teachers in planning the lessons at MTsN 3 Aceh Barat was in a good category. This can be proven by the results of the learning planning in the first cycle reaching an average of 71.35 which is included in the good category, then in the second cycle it reaches an average of 83.70 which is included in the good category. Thus, there was an increase in the implementation of learning by $12.35 \%$ and so does the improvement of learning abilities. The increase in the ability of the teacher can be proven from the results of the pre-learning cycle prediction showing an average of 68.82 and in the first cycle it increased by $11.96 \%$ with an average of 80.78 , then in the second cycle it increased again by $10.38 \%$, and reached 91.17 that is in very good category. Increasing the ability of teachers in learning planning as well as the implementation of learning activity in cycle I reached a value of 71.35, and 83,70 in cycle II. It means that there was an improvement about $12.35 \%$.
\end{abstract}

\begin{abstract}
Abstrak: Permasalahan yang menjadi dasar dari pelaksanaan kegiatan penelitian ini adalah rendahnya profesionalisme guru dalam mengajar yang diakibatkan oleh: (1) kurangnya kesempatan guru mengikuti pelatihan, baik secara regional maupun nasional; (2) kurang efektifnya Kelompok Kerja Guru (KKG); dan (3) supervisi pendidikan yang bertujuan memperbaiki proses pembelajaran cenderung menitikberatkan pada aspek administrasi. Penelitian dilakukan pada guru di MTsN 3 Aceh Barat Tahun Pelajaran 2018 yang dimulai bulan Juli sampai Desember, selama 6 (enam) bulan. Subjek penelitian sebanyak 6 orang guru, adapun objek penelitiannya adalah adalah profesionalisme guru dalam melaksanakan pembelajaran. Teknik pengumpulan data dengan kegiatan observasi dan dokumentasi. Hasil penelitian menunjukkan Profesionalisme guru dalam perencanaan pembelajaran di MTsN 3 Aceh Barat dalam kategori baik. Hal ini dapat dibuktikan dengan melalui hasil penilaian perencanaan pembelajaran pada siklus I mencapai nilai rata-rata 71,35 termasuk dalam kategori baik, kemudian pada siklus II mencapai nilai rata-rata 83,70 termasuk dalam kategori baik. Dengan demikian terjadi peningkatan pelaksanaan pembelajaran sebesar $12,35 \%$. Sedangkan peningkatan kemampuan melaksanakan pembelajaran. Peningkatan kemampuan guru tersebut dapat dibuktikan dari hasil penilaian pra pembelajaran pra siklus menunjukkan rata-rata 68,82 dan pada siklus I meningkat sebesar 11,96 \% dengan nilai rata-rata 80,78, kemudian pada siklus II meningkat lagi sebesar 10,38 \% menjadi 91,17 dengan kategori sangat baik. Peningkatan kemampuan guru dalam pra pembelajaran/perencanaan pembelajaran tersebut sekaligus diikuti dengan peningkatan kemampuan guru dalam melaksanakan pembelajaran pada siklus I mencapai nilai sebesar 71,35 dan pada siklus II mencapai nilai rata-rata sebesar 83,70, maka terjadi peningkatan sebesar 12,35 \%.
\end{abstract}




\section{A. Pendahuluan}

Supervisor yang paling dekat dan senantiasa berdampingan dengan guru adalah kepala sekolah. Menurut Sudarwan Danim, kepala sekolah adalah guru yang mendapat tugas tambahan sebagai kepala sekolah (Danim 2010:145). Sementara menurut (Daryanto 2011:136), kepala sekolah adalah pemimpin pada suatu lembaga satuan pendidikan. Kepala ialah adalah pemimpin yang proses kehadirannya dapat dipilih secara langsung, ditetapkan oleh yayasan, atau ditetapkan oleh pemerintah

Adapun menurut Sri Damayanti (Asmani 2012:16) kepala sekolah berasal dari dua suku kata yaitu " Kepala " dan " Sekolah ". Kata " Kepala " dapat diartikan sebagai ketua atau pemimpin dalam satu organisasi atau lembaga, sedangkan sekolah diartikan sebagai sebuah lembaga tempat menerima dan memberi pelajaran.

Berdasarkan beberapa pendapat tersebut, secara garis besar, dapat disimpulkan bahwa kepala sekolah adalah seorang guru yang mempunyai kemampuan untuk memimpin segala sumber daya yang ada di suatu sekolah, sehingga dapat didayagunakan secara maksimal untuk mencapai tujuan Bersama.

Untuk meningkatkan mutu pendidikan di Indonesia, pemerintah telah menetapkan Undang-Undang Sistem Pendidikan. Undang-undang tersebut memuat dua puluh dua bab, tujuh puluh tujuh pasal, dan penjelasannya. Undang-Undang Sistem Pendidikan 2003 menjelaskan bahwa setiap pembaruan sistem pendidikan nasional untuk memperbarui visi, misi, dan strategi pembangunan pendidikan nasional. Visi pendidikan nasional di antaranya adalah: (1) mengupayakan perluasan dan pemerataan kesempatan memperoleh pendidikan yang bermutu bagi seluruh rakyat Indonesia; (2) membantu dan memfasilitasi pengembangan potensi anak bangsa secara utuh sejak usia dini sampai akhir hayat dalam rangka mewujudkan masyarakat belajar; (3) meningkatkan kesiapan masukan dan kualitas proses pendidikan untuk mengoptimalkan pembentukan kepribadian yang bermoral; (4) meningkatkan keprofesionalan dan akuntabilitas lembaga pendidikan sebagai pusat pembudayaan ilmu pengetahuan, keterampilan, pengalaman, sikap, dan nilai berdasarkan standar nasional dan global;dan (5) memperdayakan peran serta masyarakat dalam penyelenggaraan pendidikan berdasarkan prinsip otonomi dalam konteks Negara Kesatuan RI.

Guru menjadi sektor pendukung untuk pengoptimalisasian terealisasinya peningkatan pendidikandikarenakan guru akan menjalankan tugas dengan baik jika guru telah memahami dan menjalankan empat kompetensi guru sehingga guru dapat disebut sebagai guru profesional. Harapannya dengan guru yang profesional yang memahami dan mengembangkan empat kompetensi guru akan membantu para guru mencapai tujuan pendidikan dan berusaha mencapai tujuan pendidikan itu dengan mengembangkan metode-metode dan prosedur pengajaran yang lebih baik (Kristiawan, 2016). Seorang guru harus selalu meningkatkan kemampuan profesionalnya menurut Kunandar (2014:46) profesionalisme adalah kondisi, arah, tujuan, dan kualitas suatu keahlian dan kewenangan yang berkaitan dengan mata pencaharian seseorang. Sedangkan Wijaya (2018:13) profesionalisme guru berkaitan dengan komitmen para anggota suatu profesi untuk meningkatkan kemampuan profesionalismenya dan terus menerus mengembangkan strategi yang dugunakannya dalam melakukan pekerjaan yang sesuai dengan profesinya. Profesionalisme menyangkut kecocokan antara kemampuan yang dimiliki oleh birokrasi dengan kebutuhan tugas, terpenuhi kecocokan kemampuan dan kebutuhan tugas merupakan syarat terbentuknya aparatur yang profesional. 
Sedarmayanti (2010:96) adalah pilar yangakan menempatkan birokrasi sebagai mesin efektif bagi pemerintah dan sebagai parameter kecakapan aparatur dalam bekerja secara baik. Sejalan dengan Mardapi (2012:5) menyatakan guru profesional adalah guru yang mampu menguasai karakteristik bahan ajar dan karakteristik peserta didik. Berdasarkan defenisi diatas dapat disimpulkan bahwa profesionalisme adalah suatu suatu keahlian dalam jabatan tertentu yang mensyaratkan kompetensi (pengetahuan, sikap, dan ketrampilan) tertentu secara khusus yang diperoleh dari pendidikan akademis yang intensif. Seorang profesional menjalankan kegiatannya berdasarkan profesionalisme, dan bukan secara amatiran. Profesionalisme bertentangan dengan amatirisme. Seorang professional akan terus-menerus meningkatkan mutu karyanya secara sadar, melalui pendidikan dan pelatihan. Paradigma baru pendidikan yang menerapkan Manajemen Berbasis Sekolah (MBS) dan Kurikulum K 13. Menurut Ditjen Pendidikan Dasar dan Menengah, Departemen Pendidikan Nasional, seorang guru harus memenuhi tiga standar kompetensi, di antaranya: (1) kompetensi pengelolaan pembelajaran dan wawasan kependidikan, (2) kompetensi akademik/vokasional sesuai materi pembelajaran, dan (3) pengembangan profesi. Ketiga kompetensi tersebut bertujuan agar guru bermutu menjadikan pembelajaran bermutu juga, yang akhirnya meningkatkan mutu pendidikan di Indonesia.

Untuk mencapai tiga kompetensi tersebut, Pengawas Sekolah bersama dengan kepala sekolah harus melaksanakan pembinaan terhadap guru baik melalui workshop, KKG, diskusi, dan supervisi edukatif. Hal itu harus dilakukan secara periodik agar kinerja dan wawasan guru bertambah. Sebab, berdasarkan diskusi yang dilakukan guru di MTsN 3 Aceh Barat, rendahnya kinerja dan wawasan guru diakibatkan oleh: (1) rendahnya kesadaran guru untuk belajar; (2) kurangnya kesempatan guru mengikuti pelatihan, baik secara regional maupun nasional; (3) kurang efektifnya KKG; dan (4) supervisi pendidikan yang bertujuan memperbaiki proses pembelajaran cenderung menitikberatkan pada aspek administrasi.

Supervisi menurut Sri Banun (2010:95-96) menjelaskan bahwa supervisi yang tidak secara langsung berkaitan dengan berkaitan dengan perbaikan pengajaran tersebut, bisa pula dikategorikan sebagai supervisi administrasif. Pada hakekatnya supervisi merupakan salah satu fungsi pokok dari manajemen pendidikan, yaitu melakukan kontrol jaminan bahwa pembelajaran dilaksanakan dengan benar dan berkualitas. Oleh karena itu, kegiatan supervisi ini hendaknya rutin dilaksanakan di sekolah sebagai salah satu kegiatan yang dipandang positif dalam meningkatkan proses pembelajaran. Apabila konsep-konsep ideal tersebut dilaksanakan, maka dapat diharapkan kualitas pendidikan akan meningkat secara signifikan.

Berdasarkan pengamatan awal bahwa terdapat kesan guru belum melaksanakan tugasnya secara optimal dalam pembelajaran. Guru masih ada yang melaksanakan pembelajaran secara tradisional, kurang sistematis serta kurang memperhatikan metode dan teknik pembelajaran. Pembelajaran yang kurang sistematis maka hasil pembelajaran juga tidak maksimal. Untuk melaksanakan pembelajaran yang sistematis guru harus membuat persiapan mengajar, mempersiapkan sarana prasarana pembelajaran yang diperlukan, membuka pelajaran dengan baik, memotivasi siswa untuk belajar, menyampaikan tujuan pembelajaran secara jelas, menyampaikan materi pelajaran dengan jelas dan dapat diterima siswa, mengaktifkan siswa dalam pembelajaran, mengevaluasi hasil pembelajaran dan bersama siswa guru menyimpulkan materi pelajaran. 
Kesenjangan yang terjadi adalah masih ada guru yang belum maksimal dalam pelaksanaan pembelajaran, sehingga diperlukan motivasi eksternal bagi guru. Untuk memotivasi guru agar melaksanakan pembelajaran secara optimal maka kepala sekolah dan pengawas perlu mengefektifkan kembali supervisi kelas terhadap beberapa guru di MTsN 3 Aceh Barat. Supervisi kelas yang akan dilakukan meliputi tiga tahap kegiatan yaitu: 1) pengawas, kepala sekolah, dan guru mengadakan pertemuan awal untuk membuat kesepakatan pelaksanaan supervisi kelas, guru dapat menggali berbagai macam informasi tentang persiapan pembelajaran, sebaliknya kepala sekolah dan pengawas dalam hal ini dapat memberikan pembinaan untuk perbaikan perencanaan pembelajaran 2) pelaksanaan pembelajaran, pengawas dibantu oleh kepala sekolah mengamati, mengevaluasi pelaksanaan pembelajaran guru, 3) pengawas berdasarkan hasil diskusi dengan kepala sekolah menyampaikan kelemahan dan kelebihan guru dalam mengajar serta membimbing dan memberikan saran perbaikan, sehingga kelemahan-kelemahan itu tidak akan terjadi pada pembelajaran berikutnya.

\section{B. Metode}

Metode pengumpulan data dalam penelitian ini dilakukan melalui beberapa cara diantaranya observasi dan dokumentasi. Menurut Sugiyono (2015:227), penelitian dimulai dengan mencatat, menganalisis dan selanjutnya membuat kesimpulan tentang pelaksanaan dan hasil program yang dilihat dari ada atau tidaknya perkembangan usaha yang dimiliki warga belajartempat, orang, benda-benda, maupun kegiatan-kegiatan yang sedang berlangsung. Sedangkan dokumentasi menurut Sugiyono (2015:329) adalah suatu cara yang digunakan untuk memperoleh data dan informasi dalam bentuk buku, arsip, dokumen, tulisan angka dan gambar yang berupa laporan serta keterangan yang dapat mendukung penelitian.

Teknik analisis data yang digunakan adalah model alur yang terekam dalam catatan lapangan, yang terdiri dari tiga alur kegiatan yang berlangsung secara bersamaan, yaitu reduksi data, penyajian data, dan penarikan kesimpulan.

\section{Hasil dan Pembahasan}

Pembahasan hasil penelitian didasarkan pada hasil pra siklus, hasil tindakan siklus I dan hasil tindakan siklus II. Penelitian tindakan sekolah ini dilaksanakan melalui 2 tahap, yaitu siklus I dan siklus II. Pembahasan hasil penelitian tersebut terdiri dari penilaian pra pembelajaran yang meliputi 5 aspek, yaitu: (1) pra pembelajaran; (2) pembukaan pembelajaran; (3) penguasaan materi pelajaran; (4) pendekatan/strategi pembelajaran; (5) pemanfaatan sumber belajar/media pembelajaran; (6) pembelajaran yang memicu dan memelihara keterlibatan siswa; (7) penilaian proses dan hasil belajar; (8) penggunaan bahasa, dan (9) menutup pelajaran.

Kegiatan tindakan dilakukan sebelum tindakan siklus I. hal ini dilakukan dengan tujuan untuk mengetahui gambaran kondisi awal kemampuan guru sebelum mengikuti siklus I. Setelah melaksanakan kegiatan, menganalisis, peneliti melakukan tindakan siklus I dan siklus II.

Dalam penelitian ini peneliti dibantu oleh kepala sekolah untuk melakukan observasi. Pada hari berikutnya sesuai dengan jadwal mengajar masing-masing guru dilakukan supervisi kunjungan kelas untuk menilai kemampuan guru dalam melaksanakan pembelajaran. Semua kegiatan tersebut dilakukan hingga dua kali, yaitu siklus I dan siklus 
II pada tempat yang sama. Pada akhir kegiatan dilakukan penelitian pra pembelajaran, yang hasilnya dapat dilihat pada tabel 1.

Tabel 1.

Rekapitulasi Penilaian Peningkatan Profesionalisme Guru Pada Kegiatan Perencanaan Pembelajaran Kondisi Awal, Siklus I, dan II

\begin{tabular}{|c|c|c|c|c|c|c|}
\hline \multirow[b]{2}{*}{ No } & \multirow[b]{2}{*}{ Aspek Penilaian } & \multicolumn{3}{|c|}{ Nilai Rata-Rata } & \multicolumn{2}{|c|}{ Peningkatan \% } \\
\hline & & $\begin{array}{c}\text { Pra } \\
\text { siklus }\end{array}$ & $\begin{array}{c}\text { Siklus } \\
\text { I }\end{array}$ & $\begin{array}{l}\text { Siklus } \\
\text { II }\end{array}$ & $\begin{array}{c}\text { Pra - } \\
\text { Siklus } \\
\text { I }\end{array}$ & $\begin{array}{c}\text { Siklus } \\
\text { I - II }\end{array}$ \\
\hline 1. & Perumusan tujuan & 53,33 & 67,78 & 81,11 & 14,44 & 13,33 \\
\hline 2. & Penjabaran materi & 58,33 & 78,33 & 90,83 & 20,00 & 12,50 \\
\hline 3. & Alat/bahan pelajaran & 53,33 & 70,00 & 88,89 & 16,67 & 18,89 \\
\hline 4. & Langkah-langkah PBM & 55,83 & 80,00 & 90,83 & 24,17 & 10,83 \\
\hline 5. & Penilaian & 60,00 & 81,11 & 92,22 & 21,11 & 11,11 \\
\hline \multicolumn{2}{|c|}{ Rata-rata } & 56,17 & 75,44 & 88,78 & 19,28 & 13,33 \\
\hline
\end{tabular}

Dalam bentuk grafik peningkatan peningkatan profesionalisme guru pada kegiatan pelaksanaan pembelajaran per aspek penilaian sebagaimana gambar 1

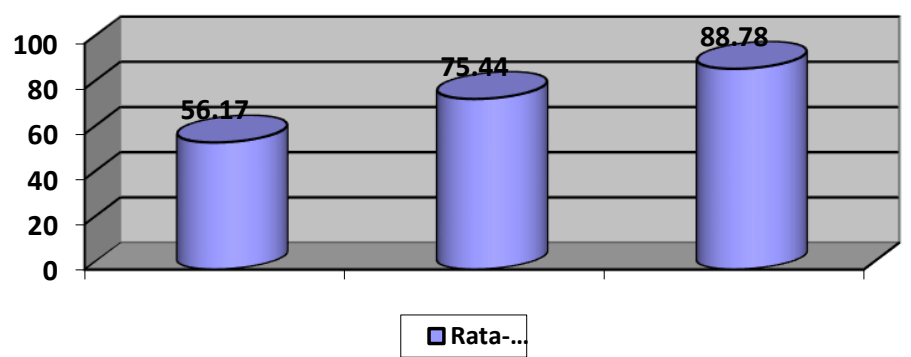

Gambar 1.

Grafik Peningkatan Peningkatan Profesionalisme Guru Pada Kegiatan Perencanaan Pembelajaran Per Aspek Penilaian

Berdasarkan rekapitulasi data pada tabel di atas, hasil penilaian pra pembelajaran dari pra siklus, siklus I, sampai siklus II sebagaimana tersaji dalam tabel di atas, dapat dijelaskan bahwa kemampuan guru pada setiap aspek penilaian pra pembelajaran semua mengalami peningkatan.

Pada siklus I, hasil pada aspek perumusan tujuan pembelajaran sebesar 67,78 termasuk kategori cukup. Hal ini dikarenakan guru sudah memahami rumusan tujuan pembelajaran. Pada aspek penjabaran materi nilai rata-rata sebesar 78,33 termasuk dalam kategori baik, karena guru sudah dapat memilih dan mengorganisasikan materi ajar. Aspek alat/bahan pelajaran nilai rata-rata sebesar 70,00 dalam kategori cukup, dalam hal ini guru belum maksimal terhadap pemilihan sumber belajar/materi pelajaran. Aspek langkahlangkah PBM nilai rata-rata sebesar 80,00 termasuk dalam kategori baik berarti guru sudah dapat menentukan langkah-langkah PBM temasuk pemilihan metode mengajar yang sesuai dengan tujuan pembelajaran, materi dan karekteristik siswa. Aspek penilaian mencapai nilai rata-rata 81,11 dalam kategori baik terutama dalam aspek ini guru memahami tentang 
penilaian hasil belajar secara lengkap yang meliputi: kisi-kisi soal, kunci jawaban, norma penilaian.

Pada siklus II, hasil pada aspek perumusan tujuan pembelajaran sebesar 81,11 termasuk kategori baik. Hal ini dikarenakan guru sudah memahami rumusan tujuan pembelajaran. Pada aspek penjabaran materi nilai rata-rata sebesar 90,83 termasuk dalam kategori baik, karena guru sudah dapat memilih dan mengorganisasikan materi ajar. Aspek alat/bahan pelajaran nilai rata-rata sebesar 88,89 dalam kategori baik, dalam hal ini guru belum maksimal terhadap pemilihan sumber belajar/materi pelajaran. Aspek langkahlangkah PBM nilai rata-rata sebesar 80,00 termasuk dalam kategori baik berarti guru sudah dapat menentukan langkah-langkah PBM temasuk pemilihan metode mengajar yang sesuai dengan tujuan pembelajaran, materi dan karekteristik siswa. Aspek penilaian mencapai nilai rata-rata 92,22 dalam kategori sangat baik terutama dalam aspek ini guru memahami tentang penilaian hasil belajar secara lengkap yang meliputi: kisi-kisi soal, kunci jawaban, norma penilaian.

\section{Aspek Pelaksanaan Pembelajaran}

Rencana pembelajaran yang telah dilaksanakan penilaiannya, pada hari berikutnya dipakai sebagai pedoman dalam melaksanakan pembelajaran di kelas untuk mengetahui kemampuan guru dalam melaksanakan pembelajaran. Penilaian pelaksanaan pembelajaran dapat dilihat hasilnya pada tabel 2.

Tabel 2.

Rekapitulasi Penilaian Peningkatan Profesionalisme Guru Pada Kegiatan Pelaksanaan Pembelajaran per Aspek Kondisi Awal, Siklus I, dan II

\begin{tabular}{|cllcccc|}
\hline \multirow{2}{*}{ No } & Aspek Penilaian & \multicolumn{2}{c}{ Nilai Rata-Rata } & \multicolumn{3}{c}{$\begin{array}{c}\text { Peningkatan } \\
\text { \% }\end{array}$} \\
\cline { 3 - 7 } & & $\begin{array}{c}\text { Pra } \\
\text { siklus }\end{array}$ & $\begin{array}{c}\text { Siklu } \\
\text { s I }\end{array}$ & $\begin{array}{c}\text { Siklu } \\
\text { s II }\end{array}$ & $\begin{array}{c}\text { Pra - } \\
\text { Siklu } \\
\text { s I }\end{array}$ & $\begin{array}{c}\text { Siklu } \\
\text { s I - II }\end{array}$ \\
\hline 1 & Pra pembelajaran & 56,67 & 73,33 & 88,33 & 16,67 & 15,00 \\
\hline 2 & Pembukaan pembelajaran & 63,33 & 71,67 & 93,33 & 8,33 & 21,67 \\
\hline 3 & Penguasaan materi pelajaran & 58,33 & 75,00 & 88,33 & 16,67 & 13,33 \\
\hline 4 & $\begin{array}{l}\text { Pendekatan/strategi } \\
\text { pembelajaran }\end{array}$ & 63,89 & 77,22 & 95,56 & 13,33 & 18,33 \\
\hline 5 & $\begin{array}{l}\text { Pemanfaatan } \\
\text { belajar/media pembelajaran }\end{array}$ & 63,33 & 81,11 & 94,44 & 17,78 & 13,33 \\
\hline $\begin{array}{l}\text { Pembelajaran yang memicu } \\
\text { dan memelihara keterlibatan } \\
\text { siswa }\end{array}$ & & & & & \\
\hline 7 & $\begin{array}{l}\text { Penilaian proses dan hasil } \\
\text { belajar }\end{array}$ & 53,33 & 68,67 & 90,67 & 15,33 & 22,00 \\
\hline 8 & Penggunaan bahasa & 61,67 & 63,33 & 95,00 & 1,67 & 31,67 \\
\hline 9 & Menutup pelajaran & 61,67 & 73,33 & 96,36 & 4,44 & 27,78 \\
\hline Rata-rata & $\mathbf{6 0 , 3 7}$ & $\mathbf{7 2 , 1 4}$ & $\mathbf{9 2 , 8 5}$ & $\mathbf{1 1 , 7 7}$ & $\mathbf{2 0 , 7 2}$ \\
\hline
\end{tabular}


Dalam bentuk grafik peningkatan peningkatan profesionalisme guru pada kegiatan pelaksanaan pembelajaran per aspek penilaian sebagaimana gambar 2.

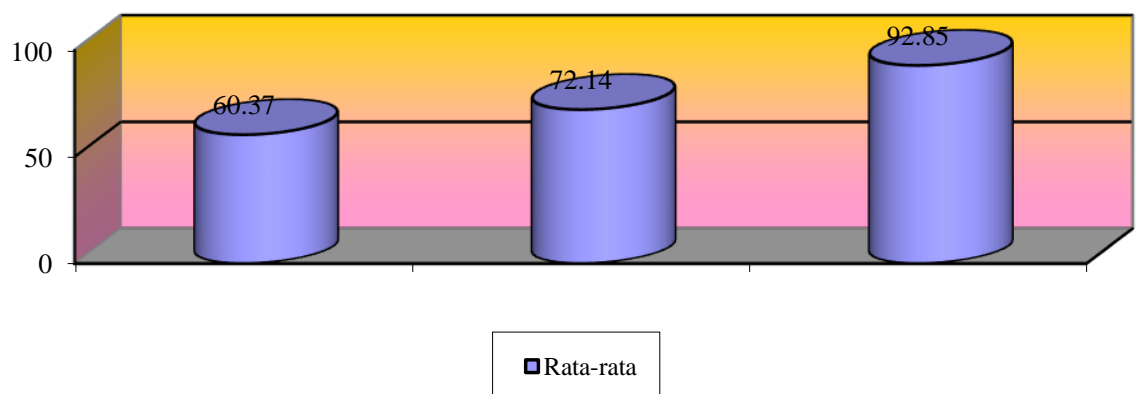

Gambar 2.

Grafik Peningkatan Peningkatan Profesionalisme Guru Pada Kegiatan Pelaksanaan Pembelajaran Per Aspek Penilaian

Berdasarkan rekapitulasi pelaksanaan pembelajaran siklus I dengan nilai rata-rata 72,14 termasuk dalam kategori cukup, karena berada dalam rentang nilai 55 - 74. Hasil tersebut belum dapat mencapai target nilai yang diharapkan yaitu 75 . Nilai rata-rata tersebut diakumulasikan dari beberapa aspek penilaian. Pada aspek pra pembelajaran sebesar 73,33 termasuk dalam kategori cukup, dalam hal ini guru sudah melaksanakan kegiatan pra pembelajaran yang meliputi pemeriksaan ruang, alat, media, siswa dengan baik. Aspek pembukaan pembelajaran sebesar 71,67 termasuk dalam kategori cukup, berarti guru sudah melaksanakan pembukaan pembelajaran dengan melakukan apresiasi, menyampaikan tujuan kompetensi yang akan dicapai dengan baik. Aspek penguasaan materi pembelajaran sebesar 75,00 termasuk dalam kategori cukup, berarti kemampuan guru dalam penguasaan materi pembelajaran cukup baik. Aspek pendekatan/strategi pembelajaran sebesar 77,22 termasuk dalam kategori baik, hal ini guru dalam menggunakan strategi pembelajaran cukup baik. Aspek pemanfaatan sumber belajar/media pembelajaran sebesar 81,11 termasuk dalam kategori baik, berarti guru dalam memanfaatkan sumber/media pembelajaran cukup baik. Aspek pembelajaran yang memicu keterlibatan siswa dalam pembelajaran sebesar 68,67 termasuk dalam kategori cukup, berarti guru sudah baik dalam memicu keterlibatan siswa dalam pembelajaran. Aspek penilaian proses dan hasil belajar sebesar 63,33 termasuk dalam kategori cukup, dalam hal ini melaksanakan penilaian proses dan hasil belajar cukup baik. Aspek penggunaan lisan nilai rata-ratanya sebesar 65,56 termasuk dalam kategori cukup, berarti guru sudah menggunakan bahasa lisan dan bahasa tulisan dengan baik. Aspek penutup pembelajaran nilai rata-ratanya 73,33 termasuk dalam kategori cukup, pada siklus ini guru belum mengakhiri pembelajaran dengan baik, hal ini dikarenakan pembagian alokasi waktu yang kurang sehingga kehabisan waktu sebelum memberi rangkuman/refleksi dan tindak lanjut.

Hasil penilaian pelaksanaan pembelajaran siklus II diperoleh nilai rata-rata sebesar 92,85 termasuk dalam kategori sangat baik karena berada pada rentang nilai 91 - 100 . Pencapaian nilai tersebut berarti sudah memenuhi target yang telah ditentukan, dengan demikian tindakan siklus III tidak perlu dilakukan. Nilai masing-masing aspek pada siklus II diuraikan sebagai berikut:

Pada aspek pra pembelajaran siklus II mencapai nilai 88,33 termasuk dalam kategori baik dan terjadi peningkatan $15 \%$ dari siklus I dengan baik. Aspek pembukaan pembelajaran siklus II mencapai nilai rata-rata 93,33 termasuk dalam kategori sangat baik 
dan terjadi peningkatan $21,67 \%$ dari siklus I karena guru melaksanakan pembukaan pembelajaran dengan sangat baik. Aspek penguasaan materi pembelajaran pada siklus II mencapai nilai rata-rata 88,33 termasuk dalam kategori baik dan terjadi peningkatan 13,33\% dari siklus I, menunjukkan bahwa guru menguasai materi ajar dengan baik. Aspek pendekatan/strategi pembelajaran siklus II mencapai nilai rata-rata 95,56 termasuk dalam kategori sagat baik dan terjadi peningkatan 18,33\% dari siklus I. Hal ini terjadi karena guru dalam penggunaan pendekatan/strategi pembelajaran sudah baik. Aspek pemanfaatan sumber/media pembelajaran siklus II mencapai rata-rata 94,44 termasuk dalam kategori baik dan terjadi peningkatan 13,33\% dari siklus I, karena guru memanfaatkan sumber/media pembelajaran dengan baik. Aspek pembelajaran yang memicu dan memelihara ketertiban siswa mencapai nilai rata-rata 90,67 termasuk dalam kategori baik dan terjadi peningkatan $22,00 \%$ dari siklus I, karena guru melaksanakan pembelajaran yang memicu dan memelihara ketertiban siswa dengan baik. Aspek penilaian proses dan hasil belajar siklus II mencapai nilai rata-rata 95,00 termasuk dalam kategori sangat baik, dan terjadi peningkatan $31,67 \%$ dari siklus I karena guru telah melaksanakan penilaian proses dan hasil belajar siswa dengan baik. Aspek penggunaan bahasa siklus II mencapai nilai ratarata 93,33termasuk dalam kategori baik dan terjadi peningkatan sebesar 27,78 \% dari siklus I, karena guru menggunakan bahasa tulis dan bahasa lisan dengan baik dan lancar. Aspek penutupan pembelajaran siklus II mencapai nilai rata-rata sebesar 96,67 termasuk dalam kategori sangat baik dan terjadi peningkatan 23,33 \% dari siklus I, peningkatan ini dikarenakan guru sudah melaksanakan penutupan pembelajaran, yaitu melakukan refleksi/rangkuman dan melaksanakan tindak lanjut dengan baik.

Peningkatan nilai pra pembelajaran sebesar $11,96 \%$ dari pra siklus ke siklus I, sebesar 10,38 \% dari siklus I ke siklus II, sebesar 22,35 \% dari pra siklus ke siklus II, yang diikuti dengan peningkatan nilai pelaksanaan pembelajaran sebesar 12,35 \% dari siklus I ke siklus II dapat menunjukkan adanya peningkatan kemampuan sikap profesionalisme guru dalam pelaksanaan pembelajaran.

Berdasarkan data pada lembar pengamatan siklus I dan siklus II, maka hasil pengamatan pelaksanaan kunjungan kelas dan pengamatan pelaksanaan pembelajaran siklus I dengan skor 72,14 termasuk dalam kategori cukup dan hasil pengamatan pada siklus II mencapai nilai 92,85 termasuk dalam kategori baik, berarti terjadi peningkatan sebesar 20,72 dari siklus I ke siklus II.

Berdasarkan dari serangkaian analisis data pelaksanaan kunjugan kelas untuk mengetahui profesionalisme guru dalam melaksanakan pembelajaran, telah terjadi perubahan perilaku guru yang positif, maka menunjukkan tingkat profesionalisme guru dalam pelaksanaan pembelajaran. Hasil penilaian pra pembelajaran yang cenderung meningkat diikuti dengan hasil penilaian pelaksanaan pembelajaran yang meningkat pula, ini menunjukkan adanya peningkatan profesionalisme guru dalam melaksanakan pembelajaran.

Dengan demikian dapat disimpulkan bahwa dengan adanya supervisi kelas melalui kunjungan kelas dapat membantu guru dalam meningkatkan profesionalisme guru dalam pelaksanaan pembelajaran sehingga pada akhirnya dapat meningkatkan kualitas KBM yang baik dan menyenangkan.

\section{Kesimpulan}

Berdasarkan rumusan masalah, hasil penelitian dan pembahasan dalam penelitian ini dapat disimpulkan sebagai berikut: 
1. Profesionalisme guru dalam perencanaan pembelajaran di MTsN 3 Aceh Barat setelah supervisi kelas melalui kunjungan kelas dalam kategori baik. Hal ini dapat dibuktikan dengan melalui hasil penilaian perencanaan pembelajaran pada siklus I mencapai nilai rata-rata 71,35 termasuk dalam kategori baik, kemudian pada siklus II mencapai nilai rata-rata 83,70 termasuk dalam kategori baik. Dengan demikian terjadi peningkatan pelaksanaan pembelajaran sebesar 12,35\%.

2. Guru di MTsN 3 Aceh Barat setelah disupervisi melalui kunjungan kelas pra pembelajaran yaitu kemampuan menyusun perencanaan pembelajaran yang sekaligus dapat mengalami peningkatan kemampuan melaksanakan pembelajaran. Peningkatan kemampuan guru tersebut dapat dibuktikan dari hasil penilaian pra pembelajaran pra siklus menunjukkan rata-rata 68,82 dan pada siklus I meningkat sebesar 11,96 \% dengan nilai rata-rata 80,78, kemudian pada siklus II meningkat lagi sebesar 10,38 \% menjadi 91,17 dengan kategori sangat baik. Peningkatan kemampuan guru dalam pra pembelajaran/perencanaan pembelajaran tersebut sekaligus diikuti dengan peningkatan kemampuan guru dalam melaksanakan pembelajaran pada siklus I mencapai nilai sebesar 71,35 dan pada siklus II mencapai nilai rata-rata sebesar 83,70, maka terjadi peningkatan sebesar 12,35\%. Dengan demikian dapat disimpulkan bahwa melalui kegiatan supervisi kelas dengan kunjungan kelas dan meningkatakan profesionalisme guru dalam melaksanakan pra pembelajaran/perencanaan pembelajaran dan dapat mengingkatkan kemampuan melaksanakan pembelajaran di MTsN 3 Aceh Barat.

\section{Daftar Pustaka}

Daryanto. (2011). Kepala Sekolah Sebagai Pemimpin Pembelajaran. Yogyakarta: Gava Media.

Jamal, M.A. (2012). Tips Menjadi Kepala Sekolah Profesional. Jogjakarta: DIVA Press.

Kristiawan, M. (2016). Telaah Revolusi Mental dan Pendidikan Karakter dalam Pembentukkan Sumber Daya Manusia Indonesia Yang Pandai dan Berakhlak Mulia.Ta'dib,18(1), 13-25.

Kunandar. (2014). Langkah mudah penelitian tindakan kelas sebagai pengembangan profesi guru .Jakarta : Rajawali Pers.

Mardapi, Djemari. (2012). Pengukuran, Penilaian, dan Evaluasi Pendidikan. Yogyakarta. Nuha Medika.

Sedarmayanti. (2010). Sumber Daya Manusia dan Produktivitas Kerja. CV Mandar Maju, Bandung.

Sri, B. M. (2010). Supervisi Pendidikan Meningkatkan Kualitas Profesionalisme Guru. Mataram: Alfabeta.

Sudarwan, D. (2010). Inovasi Pendidikan Dalam Upaya Peningkatan Profesonalisme Tenaga Kependidikan. Bandung: Pustaka Setia. 
Sugiyono. (2015). Metode Penelitian Kombinasi (Mix Methods). Bandung: Alfabeta.

Wijaya, I. (2018). Profesional Teacher: Menjadi Guru Profesional. Sukabumi: CV Jejak. 